\title{
Sorption of copper, lead and zinc on bentonite sediment material
}

\author{
Ibrahim. O. M. Matoug \\ Azzaytuna University Libya
}

\begin{abstract}
The retention studies of $\mathrm{Cu}, \mathrm{Pb}$ and $\mathrm{Zn}$ on bentonite materials samples, in the laboratory to understanding metal adsorption between solution phase and solid phase of the suspended materials. The metals adsorption shows different adsorption responses between these materials. In the bentonite case the most of heavy metal $\mathrm{Cu}, \mathrm{Pb}$ and $\mathrm{Zn}$ concentration was measured in the solid phase, which consequence a high $K_{d}$ value.
\end{abstract}

\section{Introduction}

In the water, system the suspended sediment is contains of sand, clay and other silicate minerals and hydrous metal oxides, as well as organic particle such as microorganisms, diatoms and plant detritus (Hart et al, 1982). A mixture of factors such as natural efficiency, soil, flora, water cycle, and element controls the availability of metals in the fluvial system (Jain and Sharma 2001; Zhang and Huang 1993; Aurada et al.,1983; Warren et al.,1981). The most of the metals load is held and distributed by suspended particulate matter in river system environments (Covelli et al., 2007). Several earlier studies suggest that suspended particles can play an important role in carrying metals in the river system (Giesy and Briese 1977; Reuter and Perdue 1977; Hoffmann et al.,1981; Salbu et al., 1985; Tanizaki et al.,1992; Dai and Martin 1995; Ross and Sherrell 1999, Hill et al 2001).

The heavy metal transported in fluvial system in the both dissolved form, and adsorbed to the surface coating of the suspended particulate matter (Gallo et al 2006). In addition, there is some important as carrier particles for oxides and organic matter coating and hydrous Fe and Mn oxides. Moreover, organic matter influences heavy metal partitioning onto suspended particle like Mineral surfaces such as clays and alumino silicates (Horowitz, et al 1991). The exchange of metal ions between water and sediment is an important process to study the metals transport in the water system (Singh, et al 2005).

Suspended materials nature can control metals absorption rate and the availability of dissolved metals. Metal is linked easily to clay materials that may be because the chemical and physical properties of the clay materials such as a high ion exchange capacity (Boenigk et al., 2005). The correlation between the concentrations of trace metal and sediment are important, which may be due to the change in total surface area of the sediment in suspension (Bradley et al., 1982). The surface area of a sediment particle controls the surface chemistry and its ability to adsorb sediment-associated contaminants (Gibbs et al., 1977, Horowitz and Elrick 1987). The fine particle size is increasing the surface area of the clay, which may be resulting increase the ability to absorption metal per unit mass (Lead et al., 1999).

Bentonite has one octahedral sheet: two tetrahedral sheets. The bentonite has largely negative charges within the crystal, because of the extensive isomorphous substitution. The interlayer bonding is weak, which results in high cation exchange capacity (CEC) $\left(800-1200 \mathrm{mmol} \mathrm{Kg}^{1-}\right)$ and high surface area $\left(800 \times 10^{3} \mathrm{~m}^{2} \mathrm{Kg}^{-1}\right)$ of the bentonite (Bohn, 2001). The amount of the surface layer charge plays an important role in determining the strength and type of bonding layers. If the layer charge is zero, very weak Van der Waals forces bond the layer together. On the other hand, the bonding is strong when the layer charge is negative, because cations go between the unit layers.

The distribution coefficient $\left(\mathrm{K}_{\mathrm{d}}=[\mathrm{metal}]_{\text {solid }} /[\text { metal }]_{\text {solution }}\right)$ was determined for each system as a function of adsorbent concentration. $\mathrm{K}_{\mathrm{d}}$ values have frequently been used to assess the relative concentration of metals in solution associated with suspended materials (Yin et al 2002). The higher the $K_{d}$ value, the more metal is associated in the solid materials. Materials representative of components of suspended particles was bentonite. This study will evaluate the ability of different components of suspended material to take up heavy metals. Experiments were carried out to measure the distribution of copper, lead and zinc between an aqueous phase and solid phase sediment material. This study tries to simulate the natural system, exploring the effects of trace metals on important materials, which are commonly found in the soil.

\section{Methods}

Four representatives of bentonite sample were investigated. The samples were analysed by Atomic absorption Spectrometry a Perkin Elmer $400 \mathrm{~B}$ model. The experiment was performed by adding different masses $(0.3 \mathrm{~g}, 0.5 \mathrm{~g}, 0.8 \mathrm{~g}$ and $1 \mathrm{~g})$ of the bentonite to one litre of distilled water containing trace metal at a1mg/l concentration of metal in a clean, dry glass beaker. 
Approximately e.g. $0.3 \mathrm{~g}$ of dry material was weighed in a beaker. $1 \mathrm{ml}$ of $1 \mathrm{mg} / \mathrm{l}$ concentration of metal was added to one litre of distilled water. The $0.3 \mathrm{~g}$ of the material was added to the $1 \mathrm{mg} / \mathrm{l}$ concentration solution. A stirrer bar was added and the beaker placed on a magnetic stirrer for mixing the sample. The sample was mixed for times ranging between 15 and 30 minutes. The nylon membrane filter paper with $0.2 \square \mathrm{m}$ pore size was weighed. The sample material was filtered through $0.2 \square \mathrm{m}$ pore size filters, and the filter paper was reweighed to determine the mass of material recovered. The filter paper was digested in 3:1 hydrochloric acid /nitric acid solution, an aqua regia digest.

\section{Results and discussion}

The recovery of bentonite and distribution of $\mathrm{Cu}, \mathrm{Pb}$, and $\mathrm{Zn}$ metals between solid and solution phase are shown in table (1). The results show most of the mass was recovered. The majority of the metals were measured in the solid phase and measuring low concentrations in solution phase tend to increase $\mathrm{K}_{\mathrm{d}}$ values, which result $\mathrm{Kd}$ values are $>1$. The $\mathrm{K}_{\mathrm{d}}$ of metal ions increase with increasing mass of bentonite, except with $0.8 \mathrm{~g}$ mass with $\mathrm{Cu}$ and $\mathrm{Pb}$. The $\mathrm{K}_{\mathrm{d}}$ values for $\mathrm{Cu}$ and $\mathrm{Pb}$ were higher than for $\mathrm{Zn}$. Metals can adsorb onto bentonite in the two distinct processes, in the permanent negatively charged sites, and a smaller variable charge occurs on the edges of bentonite.

The affinity order of metal $\mathrm{K}_{\mathrm{d}}$ for bentonite are shown in table (2), were quite similar with the different masses, were $\mathrm{Pb}>\mathrm{Cu}>\mathrm{Zn}$ for $0.3 \mathrm{~g}, 0.5 \mathrm{~g}$ and $0.8 \mathrm{~g}$ of bentonite mass, this was in agreement with the findings of previous research (Gu et al 2010,Yun et al 2006, and Farrah, et al 1976, 1978,1980). On the other hand, different metals $\mathrm{K}_{\mathrm{d}}$ order with $1 \mathrm{~g}$ of bentonite were $\mathrm{Pb} \approx \mathrm{Cu}>\mathrm{Zn}$. In general the lowest $\mathrm{K}_{\mathrm{d}}$ value was found for $\mathrm{Zn}$.

were $\mathrm{Cu}>\mathrm{Zn}>\mathrm{Pb}$ for $0.3 \mathrm{~g}$ and $0.5 \mathrm{~g}$ of bentonite mass, this was in disagreement with the findings of previous research Gu et al., 2010,Yun et al., 2006, and Farrah, 1976, 1978,1980. That may be because the concentration of $\mathrm{Cu}$ and $\mathrm{Pb}$ in $1 \mathrm{~L}$ of filtered water was lower than the detection limit, for this reason, use the detection limit amount for this metal to determine the Kd value. On the other hand, different metals $\mathrm{K}_{\mathrm{d}}$ order with $0.8 \mathrm{~g}$ and $1 \mathrm{~g}$ of bentonite were $\mathrm{Zn}>\mathrm{Cu}>\mathrm{Pb}$. In general the lowest $\mathrm{K}_{\mathrm{d}}$ value was found for $\mathrm{Pb}$. The $\mathrm{K}_{\mathrm{d}}$ order may be different on the surface layer for the bentonite because of the role of so many variables (nature of sites available, nature of counter ion, etc (Farrah et al., 1980). In the current studies the difference of the $\mathrm{K}_{\mathrm{d}}$ results may come from the effects of increasing the amount of the sorbent with fixed metal concentration.

Table (1) Recovery of bentonite and distribution of $\mathrm{Cu}, \mathrm{Pb}$, and $\mathrm{Zn}$ metals between solid and solution phase

\begin{tabular}{|c|c|c|c|c|c|c|c|c|}
\hline A & $\begin{array}{c}\text { B } \\
\text { Weight of }\end{array}$ & ${ }^{*} \mathrm{C}$ & D & E & F & ${ }^{* *} \mathrm{G}$ & ${ }^{* * *} \mathrm{H}$ & ${ }^{{ }_{\mathrm{I}}} \mathrm{I}$ \\
\hline \multirow[t]{2}{*}{$\begin{array}{l}\text { Sample } \\
\text { weight (g) }\end{array}$} & $\begin{array}{l}\text { bentonite } \\
\text { recovered in } \\
\text { filter }\end{array}$ & $\begin{array}{l}\text { Recovery of } \\
\text { bentonite. }\end{array}$ & $\begin{array}{l}\text { Concentration of metal in } \\
\text { digest of recovered } \\
\text { bentorite }\end{array}$ & $\begin{array}{l}\text { Weight of metal } \\
\text { in recovered } \\
\text { bentonite }\end{array}$ & $\begin{array}{l}\text { Weight of metal } \\
\text { in } 1 \mathrm{~L} \text { of filtered } \\
\text { water }\end{array}$ & $\begin{array}{l}\text { Total weight of } \\
\text { metal recovered }\end{array}$ & $\begin{array}{l}\text { Total weight of metal } \\
\text { adjusted for recovery of } \\
\text { bentonite }\end{array}$ & $\mathrm{Kd}$ \\
\hline & (g) & (\%) & $(\mathrm{mg} / \mathrm{l})$ & (mg) & (mg) & (mg) & (mg) & \\
\hline 0.3 & 0.2845 & 94 & 9.7 & 0.97 & 0.21 & 1.2 & 1.2 & 4.6 \\
\hline 0.5 & 0.4615 & 92 & 9.9 & 0.99 & 0.21 & 1.2 & 1.3 & 4.7 \\
\hline 0.8 & 0.6082 & 76 & 5.8 & 0.58 & 0.21 & 0.79 & 0.97 & 2.8 \\
\hline 1 & 0.9233 & 92 & 7.5 & 0.75 & 0.21 & 0.96 & 1.03 & 3.6 \\
\hline \multicolumn{9}{|l|}{$1 \mathrm{mg} / \mathrm{Pb}$} \\
\hline 0.3 & 0.2767 & 92 & 5.85 & 0.585 & 0.5 & 1.085 & 1.14 & 1.2 \\
\hline 0.5 & 0.4481 & 90 & 7.59 & 0.75 & 0.5 & 1.25 & 1.33 & 1.5 \\
\hline 0.8 & 0.7447 & 93 & 6.82 & 0.68 & 0.5 & 1.18 & 1.23 & 1.4 \\
\hline 1 & 0.977 & 92 & 7.47 & 0.74 & 0.5 & 1.24 & 1.30 & 1.5 \\
\hline \multicolumn{9}{|l|}{$1 \mathrm{mg} / \mathrm{Zn}$} \\
\hline 0.3 & 0.277 & 92 & 5.78 & 0.578 & 0.25 & 0.828 & 0.88 & 2.3 \\
\hline 0.5 & 0.4754 & 95 & 6.48 & 0.648 & 0.23 & 0.878 & 0.91 & 2.8 \\
\hline 0.8 & 0.7925 & 99 & 7.77 & 0.77 & 0.27 & 1.04 & 1.05 & 2.9 \\
\hline 1 & 0.9283 & 93 & 8.01 & 0.8 & 0.12 & 0.92 & 0.98 & 6.7 \\
\hline
\end{tabular}

\section{Conclusion}

The results show most of the bentonite was recovered in the filter paper. The majority of the metal was measured in the solid phase, with only a small amount measured in the aqueous phase. That may be cause an increase in $K_{d}$ values. The high in metal $K_{d}$ may be because bentonite is swelling clay, with a high surface area and a high cation exchange capacity. In the current studies the difference of the $\mathrm{K}_{\mathrm{d}}$ results may come from the effects of increasing the amount of the sorbent with fixed metal concentration. The $\mathrm{K}_{\mathrm{d}}$ order may be different on the surface layer for the bentonite because of the role of so many variables (nature of sites available, nature of counter ion, etc (Farrah,et al 1980). That may be because of an increase in surface negative charge with increasing bentonite mass, and fixed metal concentration. 


\section{References}

[1] Aurada, K.D.1983.Physiographic and anthropogenic controls of global and regional ionic runoff, in webb, b.w Dissolved loads of rivers and surface Water Quantity Quality Relationship .Hamburg, IAHS publ.141,31-39.

[2] Boenigk. J, Wiedlroither. A, Pfandl. K.2005.Heavy metal toxicity and bioavailability of dissolved nutrients to a bacterivorous flagellate are linked to suspended particle physical properties .Aquatic Toxicology71,249-259.

[3] Bohan.H, McNeal .b, O’Connor.G, 2001.Soil Chemistry. John Wiley and Sons.

[4] Bradley. S. B, Lewin.J.1982.Transport of heavy metals on suspended sediments under high flow conditions in a mineralized Regi on of Wales.

[5] Covelo.E.F, Vega.F.A, Andrade.M.I, 2007.Competitive sorption and desorption of heavy metals by individual soil components. Journal of Hazardous Materials, 140,308-315.

[6] Dai, M.H., J, M. Martin.1995.First data on trace metal level and behaviour in two major Arctic river -estuarine systems (Ob and Yennisey) and in the adjacent Kara Sea, Russia.Earth Plant.Sci.Lett.131, 127-141.

[7] Droppo.I.G, Krishnappan.B.G, Rao.S.S, Ongley.E. 1992,.Investigation of a Sequential Filtration Technique for Particle Fractionation. Environmental Sciences \&Technology. 29,2,1995.

[8] Farrah.H, Hatton.D, Pickering.W.F.1980, The affinity of metal ions for clay surfaces.Chemical Geology, 28, 55-68.

[9] Farrah.H, Pickering .W.F.1976.Influence of clay solute interactions on aqueous heavy metal ion levels.Water, Air and Soil Pollution, 8,189-197.

[10] Farrah.H, Pickering. W.F, 1977, Extraction of heavy metals ions sorbed on clays. Water,Air and Soil Pollution,9,491-498.

[11] Forbes. E.A, Posner. A. M, Quirk. 1976,. The specific adsorption of divalent, Cd, Co, Cu, Pb and Zn, 27,154-66.

[12] Gallo.M,Trento.A,Alavrez.A,Beldomenico.H,Campagnoli.D.2006.Dissolved and particulate heavy metals in the Salado River(Santa Fe,Argentina).Water, Air and Soil Pollution174,367-384.

[13] Garcia. J. 1978. Sorption of trace quantities of cadmium by soil with different chemical and mineralogical composition. Water, Air, and Soil Pollution 9, 289-299.

[14] Gibbs, J.R., 1977. Transport phases of transition metals in the Amazon and Yukon Rivers. Geol. Soc. Am. Bull., 88: 829-843.

[15] Giesy, J.P, L.A.Briese.1977.Metals associated with organic carbon extracted from Okefenokee swamp water.Chem.Geol.20,109120.

[16] Grimme H.1968,.Adsorption of manganese cobalt copper and Zinc by goethite from dilute solutions,., Zeit fuer Pflan und Bodee, 121,1, 58-65.

[17] Gu.Xueyuan, Evans. Les J, Barabash. Sarah J.2010.Modeling the adsorption of $\mathrm{Cd}, \mathrm{Cu}, \mathrm{Ni}, \mathrm{Pb}$ and $\mathrm{Zn}$ onto montmorillonite. Geochemical et Cosmochmical Acta 74, 5718-5728.

[18] Gu.Xueyuan, Evans. Les J.2008.Surface complexation modeling of $\mathrm{Cd}, \mathrm{Cu}, \mathrm{Ni}, \mathrm{Pb}$ and $\mathrm{Zn}$ adsorption onto kaolinite .Geochemical et Cosmochmical Acta 72,267-276.

[19] Hart.B.T.1982. Uptake of trace metals by sediments and suspended particulates, a review. Hydrobiologia, 91,299-313.

[20] Hill.M.D, Aplin.C.A.2001, Role of colloids and fine particles in the transport of metals in rivers draining carbonate and silicate terrains. Limnol. Oceanogr. 46(2), 2001, 331-344.

[21] Hoffmann, M. R, E. C. Yost, S. J. Eisenreich, W.J. Maier. 1981. Characterisation of soluble and colloidal -phase metal complexes in river water by ultrafiltration.A mass-balance approach .Env.Sci.Technol.15,655-661.

[22] Horowitz, A. J. \& Elrick, K. A. 1987, "The relation of stream sediment surface area, grain size and composition to trace element chemistry", Applied Geochemistry, vol. 2, no. 4, pp. 437-451.

[23] Horowitz, A. J. A Primer on Sediment-Trace Element Chemistry; Lewis Publishers Inc.: Chelsea, MI, 1991.

[24] Jain. C. K, Sharma. M.K .2001.Distribution of trace metals in the Hindon River system, India. Journal of Hydrology 253,81-90.

[25] Jiang.J, Xu. R, Li. S, 2010, Effect of Ionic Strength and Mechanism of Cu(II) Adsorption by Goethite and $\gamma-\mathrm{Al}_{2} \mathrm{O}_{3}$., J. Chem. Eng. $55,12,5547-5552$.

[26] Lead .J.R, Taylor. H, Davison. W, Harper.M.1999.Trace metal sorption by natural particles and coarse colloids. Geochimica ET Cosmochimica Acta.63.1661-1670.

[27] Ponthieu. M, Juillot .F, Hiemstra .T ,Van Riemsdijk. W. H, Benedetti,M.F, 2006 Metal ion binding to iron oxides.Geo-chemical et Cosmochimical Acta,70,2679-2698.

[28] Reuter, J .H. E.M.Perdue.1977.Importance of heavy metal -organic matter interactions in natural waters.Geochim.Acta.41:325-334.

[29] Ross, J.M, R.M.Sherrell.1999.The role of colloids in trace metal transport and adsorption behaviour in New Jersey Pinelands streams .Limnol.Oceanogr,44,1019-1034.

[30] Salbu, B, H. E. Bjornstad, N.S. Lindstrom, E. Lydersen ,E. M. Brevik, J .P.Rambaek,P.E.Paus.1985.Size fractionation techniques in the determination of elements associated with particulate or colloidal material in natural fresh waters .Talanta 32.907-913.

[31] Schinder. P.W, Liechtip, and Westall.J.C,. 1987., Adsorption of copper, cadmium and lead from aqueous solution to the Kaonilite/water interface, Neth, J, Aqu, 35,219-230.

[32] Shukla L. M, 2000,. Sorption of zinc and cadmium on soil clays,. Agrochimica, 44,3-4, 101-106.

[33] Singh.K.P, Mohan.D, Singh.V.K, Malik.A.2005.Studies on distribution and fractionation of heavy metals in Gomti river sedimentsatributary of the Ganges, India. Journal of Hydrology 312,14-27.

[34] Spark, K, M.Johnson, B.B, Wells, J.D.1995,. Characterizing heavy metal adsorption on oxide and oxyhydroxides, Eur, J, Soil, 46,621-631.

[35] Tanizaki, Y, T.Shimokawa, M.Nakmura.1992.Physicochemical speciation of trace elements in river water by size fractionation. Env.Sci.Technol.26, 1433-444.

[36] Warren. L.J.,1981. Contamination of sediments by lead, zinc and cadmium- areview. Environ. Pollution,ser 2,401-436.

[37] Yin. Y, Impellitteri. Christopher A, You. Sun-Jae, Allen. H. E., 2002. The importance of organic matter distribution and extract soil: solution ratio on the desorption of heavy metals from soils. The Science of the Total Environment 287.107,119.

[38] Yun. 1, Xing,S. Qiming.X,Haidong.C,Huixian.Z,Shixiang.G.,2006.,Adsorption of copper and lead in aqueous solution onto bentonite modified by 4-methylbenzo-15-crown-5.Journal of Hazardous MaterialsB,137,1149-1155.

[39] Zhang, J., Huang, W.W., 1993.Dissolved trace metals in the Huanghe: the most turbid large river in the world .wat.Res, $27,1-8$. 